\title{
Assessment of knowledge, attitude and practice and associated factors of blood donation among health care workers in Ethiopia: a cross-sectional study
}

Dawit Malako ${ }^{1}$, Fissehatsion Yoseph ${ }^{2}$ and Mebratu Legesse Bekele ${ }^{1 *}$

\begin{abstract}
Background: Blood can only be given from generous donors. The main objective of this study was to assess the knowledge, attitude and practice (KAP) and associated factors of blood donation among health care workers in Wolaita Sodo University Teaching and Referral Hospital (WSUTRH), Wolaita Sodo, Ethiopia.

Methods: An institution-based cross-sectional study was conducted among 218 WSUTRH health care workers. Socio-demographic characteristics and data related to the levels of KAP of participants were collected using a self-administered questionnaire. Bivariate and multivariate logistic regression analyses were conducted using statistical package for social sciences version 20 to assess the factors associated with the practice of blood donation with $p$-value set at $<0.05$ for statistical significance.

Results: Two hundred eighteen health care workers were involved in the study among which 129 (59.2\%) were males and 89 (40.8\%) were females. Among the study participants, 180(82.6\%) had good knowledge but only $128(58.7 \%)$ were found to have a good attitude as 126(57.8\%) reported that voluntary donor is the best source of blood donation. Regrettably, only $47(21.6 \%)$ of the respondents were found to practice blood donation in their lifetime. A majority (65.5\%) of the participants did not donate blood as they have not been approached to do so. Knowledge and attitude levels of the participants were not found to be significantly associated with sociodemographic parameters study; but, only sex of the participants had shown statistically significant association with blood donation practice where males were more likely to donate blood than females (AOR = 2.59 (1.22-5.49)).

Conclusions: The overall level of knowledge was satisfactory and the level of attitude and practice was unexpectedly low. Female respondents were found to have lesser practice towards blood donation than males. Health care workers, blood banks and the hospital are demanded to design ways to update knowledge, and build its psychological benefits and make services more accessible.
\end{abstract}

Keywords: Knowledge, Attitude, Practice, Health care workers, Blood donation

\footnotetext{
*Correspondence: mebleg@gmail.com

${ }^{1}$ College of Health Sciences and Medicine, Wolaita Sodo University, Wolaita

Sodo, Ethiopia

Full list of author information is available at the end of the article
}

(c) The Author(s). 2019 Open Access This article is distributed under the terms of the Creative Commons Attribution 4.0 International License (http://creativecommons.org/licenses/by/4.0/), which permits unrestricted use, distribution, and reproduction in any medium, provided you give appropriate credit to the original author(s) and the source, provide a link to the Creative Commons license, and indicate if changes were made. The Creative Commons Public Domain Dedication waiver (http://creativecommons.org/publicdomain/zero/1.0/) applies to the data made available in this article, unless otherwise stated. 


\section{Background}

Blood is a particular body fluid that transports nutrients and oxygen to the cells and moves away the metabolic wastes from the cells. Its transfusion from generous donors is an indispensable part of modern health care which can save lives and improve health. But transfusion of infectious agents carries potential risks up on the receiver demanding particular attention [1-3].

Across the globe, over 80 million units of blood are being donated a year of which only two million in Sub-Saharan Africa where the demand is high [4]. In many developing and transitional countries, there is a wide gap between blood requirements and supplies though its timely accessibility is crucial in all health facilities. (Ambaye Dejen: Knowledge, attitude, practice and factors associated towards blood donation among health care workers in Tikur Anbessa specialized hospital, Addis Ababa, Ethiopia, unpublished) [5]. Developing countries collect less than half of the blood that they need to meet an increasing transfusion requirements due to increasing prevalence of road traffic accidents (RTA), fighting accidents, pregnancy and childbirth, and other medical conditions despite the fact that WHO acclaims its member countries to ensure a safe, adequate and uninterrupted supply of blood and blood products through voluntary unpaid blood donation. In addition, there is often lack of time or proper screening of the donated blood that leaders the general public to emotive and economic stress, significant delays in obtaining safe blood, and risk of blood-borne infections [6-10].

Ethiopian Red-cross society established the national blood transfusion services (NBTS) in 1969 which has been transferred to the Federal Ministry of Health, Ethiopia was entrusted with the responsibility of managing the blood donors, collection, testing and transfusion of blood and blood products in Ethiopia with funding from United States President's Emergency Plan for AIDS Relief (PEPFAR) through the Centers for Disease Control (CDC) since 2004 [11]. In particular to Ethiopia, some pocket studies found that there was a willingness to donate blood (Daniel Negash: Willingness to voluntarily donate blood among high school students in Addis Ababa: assessment of determinants using the theory of planned behavior, unpublished); but the actual practice of blood donation was not as per the demand where only $43 \%$ of blood was being donated though the demand was estimated to be 200, 000 units per annum $[12,13]$. As a type of blood being donated, there was a legal framework which precludes the donation other than voluntary basis [14] as per the WHO recommendation being managed by the central Ethiopian national blood bank. Hence, other types of blood donation approaches are banned in Ethiopia and not being used in clinical practice.

Thus, studying knowledge, attitude, and practices (KAP) of health care workers towards blood donation has a great positive impact over the community about the issue either directly or indirectly. They are important in the recruitment of blood donors [15] and their knowledge about blood donation, attitude towards promoting voluntary blood and donation rates (KAP) are important in recruitment of blood donors too [16, 17]. Consequently, they would involve closely and adjust their own behavior and attitude with it as the hospital in which the study was conducted was with a great challenge of blood transfusion service. The possible factors affecting blood donation in the study area would be a benchmark to design evidence-based interventions/education to health care workers that can be delivered and their outcomes (improved health care worker KAP, increased voluntary donations and blood collections). Hence, the main aim of this study was to assess knowledge, attitude and practice and the factors associated with the practice of blood donation among health care workers in Wolaita Sodo University Teaching and Referral Hospital, Wolaita Sodo, Ethiopia.

\section{Methods}

The study was conducted in Wolaita Sodo University Teaching and Referral Hospital, Wolaita Zone, Southern Ethiopia. Wolaita is a zone in Ethiopian Southern Nations, Nationalities, and People's Region (SNNPR) sharing boundaries in the south with Qucha and Boreda, in the west with Dawro Zone, in the north with Hadya, Kembata and Tembaro Zones and in the east with the Sidama Zone. The administrative center is Wolaita Sodo. It is situated at $380 \mathrm{~km}$ to the south of Addis Ababa city, the capital of Ethiopia [18]. The total population is 1.65 million or about $2.31 \%$ of the countries' population; $50.73 \%$ being male and $49.27 \%$ being female [19]. The Wolaita Sodo University Teaching and Referral Hospital was established in 1928 as a zonal hospital until June 2011 when it was amalgamated into Wolaita Sodo University. The study was conducted from November 1 to 20, 2016. An institution-based cross-sectional study design was used considering the study population being selected health care workers among all health care workers providing health services in Wolaita Sodo University Teaching and Referral Hospital who were available during the data collection period.

To determine the sample size (n) for the study, the single population proportion formula was used. A $5 \%$ 
marginal error $(d=0.05)$ and by using the maximum proportion of the previous study which was found to have an attitude level of 68\% (Ambaye Dejen: Knowledge, attitude, practice and factors associated towards blood donation among health care workers in Tikur Anbessa specialized hospital, Addis Ababa, Ethiopia, unpublished) to increase the power of the study with assumption of confidence interval to be $95 \%\left(Z^{2} \alpha / 2=\right.$ 1.96) was used to determine the minimum possible sample size. Using the formula for finite population (i.e. a total of 500 health care workers in the hospital $(\mathrm{N}))$, the sample size was calculated as depicted hereunder.

$$
\begin{aligned}
\mathrm{n}= & \left(\mathrm{Z}_{\alpha / 2}^{2} \mathrm{p}(1-\mathrm{p}) \mathrm{N}\right) /\left(\mathrm{d}^{2} \mathrm{~N}+\mathrm{Z}_{\alpha / 2}^{2} \mathrm{p}(1-\mathrm{p})\right) \\
\mathrm{n}= & 1.96 * 1.96 * .68 *(1-.68) * 500 /(0.05 * 0.05 * 500 \\
& +1.96 * 1.96 * .68 *(1-.68))=201
\end{aligned}
$$

Considering a $10 \%$ non-response rate, the total sample size was corrected to be $201+(201 * 0.1)=222$.

With regard to the sampling procedure, the study subjects were selected using stratified sampling method in such a way that sample was stratified based on their departments proportionally depending upon the number of health care workers in each department with a rationale to assess any possible association of KAP of blood donation with the health care workers of different departments and then from each strata (departments) the proportionally allotted number of respondents were drawn by using simple random sampling (lottery) technique. Accordingly, the calculated 222 study participants were selected from each department as depicted in Fig. 1.

Data were collected by using a self-administered questionnaire which was prepared in English. The questionnaire was made include sociodemographic characteristics of the participants like age, sex, religion, marital status, department, qualification, monthly income, work experience, mass media exposure and questions/parameters which were designed to assess the knowledge, attitude, and practices of blood donation.

To assure the quality of data, a structured questionnaire which was carefully adopted without changing the original meaning and context from published journals was used for this study $[4,10,20]$. On its top, the questionnaire was pretested in Dubbo St. Mary Hospital health care workers and was checked for its clarity, understandability, and completeness based on objectives and variables before distributing to the actual respondents.

After the questions and the variables were checked and ascertained for completeness, consistency, and accuracy, the data were cleaned, coded, entered, and analyzed by using statistical package for social sciences (SPSS) version 20 software. Descriptive statistics like percentage, ratio, mean, median and frequency were done. Odds ratio with 95\% CI was used to measure the association of socio-demographic and other independent variable related to the practice of blood donation. Multivariable logistic regression analysis was used to assess an independent association of predictor variables with the outcome variable.

\section{Operational definitions \\ Health care worker}

Is health professional that provides preventive, curative, promotional or rehabilitative health care services for individuals or community.

\section{Level of attitude}

Attitude is the intention of respondents of the study towards the blood donation practice. The attitude of blood

Wolaita Sodo University Teaching and Referral Hospital health care workers

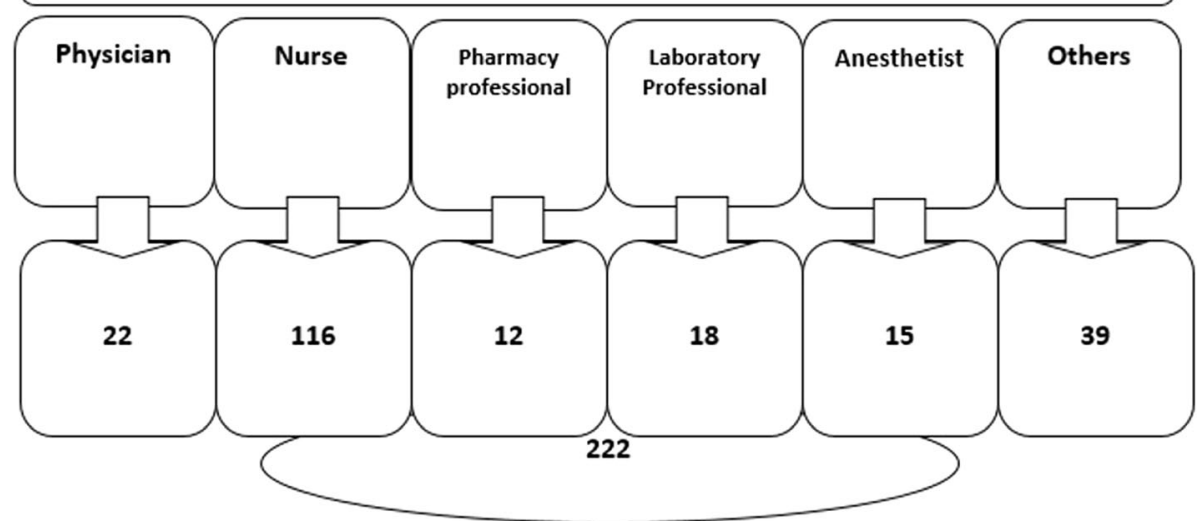

Fig. 1 Schematic illustration of samples selected 
donation was assessed through six questions. Those who scored less than the 50th percentile were categorized as having a poor attitude whereas those who scored 50th percentile or more were categorized as having a good attitude towards blood donation.

\section{Level of knowledge}

This is the understanding level of health care workers on blood donation. Based on the score of response knowledge level was categorized into having a good knowledge or poor knowledge. Knowledge level of the study subjects was assessed by using ten questions. Those who scored less than the 50th percentile were categorized as having a poor knowledge and those who scored the 50th percentile or more were categorized as having a good knowledge.

\section{Paid or remunerated donors}

Paid donors are individuals who give blood in return for money or other forms of payment.

\section{Practice of blood donation}

Practice towards blood donation denotes an experience whether an individual participant had experienced blood donation at least once in a lifetime or not at all. Those who donate blood at least once in a lifetime were categorized as having good practice whereas those who never donated blood at all in a lifetime were categorized as having poor practice towards blood donation.

\section{Regular donor}

Regular blood donor is an individual who donates blood voluntarily every $3-4$ months.

\section{Replacement donor}

Replacement donor is a donor of blood for relatives or friends to replace blood used from blood bank stocks.

\section{Results}

Out of the calculated sample size of 222, 218 were involved in the study with a non-response rate of $1.8 \%$. Among them, 129(59.2\%) were males and 89(40.8\%) were females. Nearly half of the respondents $(46.8 \%)$ were in the age group of 26-30 years and the minimum and maximum were 20 and 50 years respectively. Approximately half $(107(49.1 \%))$ were single and 106 (48.6\%) were married. Protestant Christianity and Orthodox Christianity were the predominant religions of the study subjects being represented by $107(49.1 \%)$ and $89(40.8 \%)$ respectively. Ninety-seven (44.5\%) served 1-2 years in the health facility where they were working during the study period and most of the participants were nurses (Table 1).

More than three-fourths of respondents, 169 (77.5\%) itemized that HIV, HBV, and $\mathrm{HCV}$ can be transmitted
Table 1 Socio-demographic characteristics of WSUTRH health care workers towards blood donation, 2017

\begin{tabular}{|c|c|c|c|}
\hline Variable & Category & $N$ & $\%$ \\
\hline \multirow[t]{5}{*}{ Age } & $20-25$ & 61 & 28 \\
\hline & $26-30$ & 102 & 46.8 \\
\hline & $31-35$ & 33 & 15.1 \\
\hline & $36-40$ & 15 & 6.9 \\
\hline & $\geq 41$ & 7 & 3.2 \\
\hline \multirow[t]{2}{*}{ Sex } & Male & 129 & 59.2 \\
\hline & Female & 89 & 40.8 \\
\hline \multirow[t]{4}{*}{ Marital status } & Single & 107 & 49.1 \\
\hline & Married & 106 & 48.6 \\
\hline & Divorced & 4 & 1.8 \\
\hline & Widowed & 1 & 0.5 \\
\hline \multirow[t]{4}{*}{ Qualification } & Diploma & 77 & 35.3 \\
\hline & First degree & 138 & 63.3 \\
\hline & Second degree & 1 & 0.5 \\
\hline & Specialist & 2 & 0.9 \\
\hline \multirow[t]{5}{*}{ Religion } & Protestant & 107 & 49.1 \\
\hline & Orthodox & 89 & 40.8 \\
\hline & Catholic & 9 & 4.1 \\
\hline & Muslim & 6 & 2.8 \\
\hline & Other & 7 & 3.2 \\
\hline \multirow[t]{6}{*}{ Duration of practice in years } & $1-2$ & 97 & 44.5 \\
\hline & $3-4$ & 31 & 14.2 \\
\hline & $5-6$ & 23 & 10.6 \\
\hline & $7-8$ & 31 & 14.2 \\
\hline & $9-10$ & 16 & 7.4 \\
\hline & $\geq 11$ & 20 & 9.1 \\
\hline \multirow[t]{6}{*}{ Department } & Nursing & 116 & 53.2 \\
\hline & Physician & 22 & 10.1 \\
\hline & Laboratory & 18 & 8.3 \\
\hline & Anesthetists & 15 & 6.9 \\
\hline & Pharmacy & 8 & 3.7 \\
\hline & Others & 39 & 17.9 \\
\hline \multirow[t]{4}{*}{ Monthly income in birr } & $1000-3000$ & 87 & 39.9 \\
\hline & $3001-6000$ & 81 & 37.2 \\
\hline & $6001-9000$ & 48 & 22 \\
\hline & $>9000$ & 2 & 0.9 \\
\hline \multirow[t]{2}{*}{ Easy accessibility of blood bank } & Yes & 26 & 11.9 \\
\hline & No & 192 & 88.1 \\
\hline
\end{tabular}

through blood donation whereas $17(7.8 \%)$ of the respondents listed that syphilis, malaria, and CMV can be transmitted through blood transfusion. One hundred forty $(64.2 \%)$ did know how often an individual donates blood and 78 (35.8\%) did not know the interval of blood 
Table 2 Level of knowledge of WSUTRH health care workers towards blood donation, 2017

\begin{tabular}{|c|c|c|c|}
\hline Questions & Category & $N$ & $\%$ \\
\hline \multirow{2}{*}{$\begin{array}{l}\text { Do you know common } \\
\text { blood groups? }\end{array}$} & Yes & 215 & 98.6 \\
\hline & No & 3 & 1.4 \\
\hline \multirow{2}{*}{$\begin{array}{l}\text { Do you know your } \\
\text { blood group? }\end{array}$} & Yes & 205 & 94 \\
\hline & No & 13 & 6 \\
\hline \multirow{8}{*}{$\begin{array}{l}\text { What is your blood } \\
\text { group? }\end{array}$} & $A+$ & 40 & 19.5 \\
\hline & $A-$ & 10 & 4.9 \\
\hline & $\mathrm{B}+$ & 50 & 24.4 \\
\hline & B- & 10 & 4.9 \\
\hline & $A B+$ & 19 & 9.2 \\
\hline & $A B-$ & 8 & 3.9 \\
\hline & $\mathrm{O}+$ & 59 & 28.8 \\
\hline & O- & 9 & 4.4 \\
\hline \multirow{2}{*}{$\begin{array}{l}\text { Can a person be i } \\
\text { nfected by receiving } \\
\text { blood transfusion? }\end{array}$} & Yes & 190 & 87.2 \\
\hline & No & 28 & 12.8 \\
\hline \multirow{3}{*}{$\begin{array}{l}\text { What diseases are } \\
\text { transmissible by } \\
\text { blood transfusion? }\end{array}$} & HIV, HBV \&HCV & 169 & 77.5 \\
\hline & Syphilis, Malaria, and CMV & 17 & 7.8 \\
\hline & Other diseases $^{a}$ & 32 & 14.7 \\
\hline \multirow{5}{*}{$\begin{array}{l}\text { How often an individual } \\
\text { donate blood? }\end{array}$} & Monthly & 3 & 1.4 \\
\hline & Three monthly & 140 & 64.2 \\
\hline & Six monthly & 58 & 26.6 \\
\hline & Annually & 12 & 5.5 \\
\hline & I don't know & 5 & 2.3 \\
\hline \multirow{2}{*}{$\begin{array}{l}\text { Who should donate } \\
\text { blood? }\end{array}$} & Men, women \& healthy & 195 & 89.4 \\
\hline & $\begin{array}{l}\text { Old }>60 \text { yrs., young }<18 \text { yrs. } \\
\text { vulnerable group \& diseased }\end{array}$ & 23 & 10.6 \\
\hline \multirow{3}{*}{$\begin{array}{l}\text { What volume of blood } \\
\text { is collected during each } \\
\text { donation? }\end{array}$} & $<500 \mathrm{ml}$ & 164 & 75.2 \\
\hline & $500-1000 \mathrm{mls}$ & 45 & 20.7 \\
\hline & I Don't know & 9 & 4.1 \\
\hline \multirow{3}{*}{$\begin{array}{l}\text { What is the duration of } \\
\text { the donation process? }\end{array}$} & $20 \mathrm{~min}$ & 74 & 34 \\
\hline & $20-60 \min$ & 118 & 54.1 \\
\hline & I don't know & 26 & 11.9 \\
\hline \multirow{5}{*}{$\begin{array}{l}\text { What is your primary } \\
\text { source of information } \\
\text { about blood donation? }\end{array}$} & Training/school/college & 112 & 51.4 \\
\hline & Health facility & 53 & 24.3 \\
\hline & Mass media & 39 & 17.9 \\
\hline & Others & 13 & 6 \\
\hline & Have no information & 1 & 0.5 \\
\hline
\end{tabular}

${ }^{\mathrm{a}}$ Typhoid fever, Typhus fever, Relapsing fever ${ }^{\mathrm{b}}$ Thirteen respondents did not know their blood group

donation. Twenty-three (10.6\%), 54 (24.8\%) and 146 (66.1\%) did not know who should donate blood, the volume of blood collected during each donation and the duration of donation process respectively. In general, $180(82.6 \%)$ of respondents were found to have good knowledge of blood donation (Table 2).
Table 3 Level of attitude of WSUTRH health care workers towards blood donation, 2017

\begin{tabular}{|c|c|c|c|}
\hline Questions & Category & $N$ & $\%$ \\
\hline \multirow{3}{*}{$\begin{array}{l}\text { What do you think about blood } \\
\text { donation? }\end{array}$} & Good & 216 & 99.1 \\
\hline & Bad & - & - \\
\hline & No idea & 2 & 0.9 \\
\hline \multirow{5}{*}{$\begin{array}{l}\text { What do you think is the best source } \\
\text { of blood donation? }\end{array}$} & Voluntary & 126 & 57.8 \\
\hline & Replacement & 71 & 32.6 \\
\hline & Remunerated & 2 & 0.9 \\
\hline & Self-donor & 17 & 7.8 \\
\hline & I don't know & 2 & 0.9 \\
\hline \multirow{3}{*}{$\begin{array}{l}\text { Can something harmful happen to a } \\
\text { blood donor during or after donation? }\end{array}$} & Yes & 149 & 68.3 \\
\hline & No & 57 & 26.1 \\
\hline & I don't know & 12 & 5.5 \\
\hline \multirow{3}{*}{$\begin{array}{l}\text { What can happen to a blood donor } \\
\text { during or after donation? }\end{array}$} & Contract infection & 24 & 11.6 \\
\hline & $\begin{array}{l}\text { Temporary } \\
\text { weakness }\end{array}$ & 175 & 80.3 \\
\hline & Fall sick & 7 & 3.4 \\
\hline \multirow{3}{*}{$\begin{array}{l}\text { Should patient relative be asked } \\
\text { to donate? }^{\text {a }}\end{array}$} & Yes & 166 & 76.1 \\
\hline & No & 50 & 22.9 \\
\hline & I don't know & 2 & 0.9 \\
\hline \multirow{2}{*}{$\begin{array}{l}\text { Do you encourage relatives to } \\
\text { donate? }\end{array}$} & Yes & 136 & 62.4 \\
\hline & No & 82 & 37.6 \\
\hline \multirow{2}{*}{$\begin{array}{l}\text { Will you donate if called upon or } \\
\text { reminded to do so? }\end{array}$} & Yes & 123 & 56.4 \\
\hline & No & 95 & 43.6 \\
\hline
\end{tabular}

Among the study participants, 128(58.7\%) were found to have a good attitude towards blood donation. Almost all of the respondents, 216 (99.1\%), responded that blood donation is good. But only 126(57.8\%) reported that voluntary donor is the best source of blood donation and around one-third, 71 (32.6\%) responded that it is a replacement donor. Temporary weakness was commonly assumed to happen to a donor after donation $(175(80.3 \%))$. One hundred sixty-six $(76.1 \%)$ reported that the relative of the patient should be asked to donate (Table 3).

With regard to blood donation practice, only 47 (21.6\%) were found to donate blood and only $6(2.8 \%)$ donated more than three times in their lifetime. Among the study participants who had blood donation practice, more than half of the participants practiced blood donation were in age groups less than 30 years and only 27 (12.4\%) were of their own free will. Out of the respondents those who did not donate blood, most (112 $(65.5 \%))$ reasoned as they were not approached to donate. In addition, fear of needle and fear of knowing their own sero-status were among the reasons described by the participants that could hinder donation. Among all non-donors, 25 (11.5\%) responded 
Table 4 Level of practice of WSUTRH health care workers towards blood donation, 2017

\begin{tabular}{llll}
\hline Questions & Category & $N$ & $\%$ \\
\hline Have you ever donated & Yes & 47 & 21.6 \\
blood? & No & 171 & 78.4 \\
How often do you donate & Once & 28 & 12.8 \\
in a year? & 2-3 times & 13 & 6 \\
& More than 3 times & 6 & 2.8 \\
Why did you donate? & A friend or relative & 20 & 9.2 \\
& needed blood & & \\
& Voluntarily & 27 & 12.4 \\
& Remunerated (paid) & - & - \\
& To know my screen status & - & - \\
& Not approached to donate & 112 & 51.4 \\
Reasons for non-donation & Unfit to donate & 7 & 3.2 \\
by non-donors & Fear of needle & 15 & 6.9 \\
& Fear of knowing my status & 10 & 4.6 \\
& Religion forbids it & 1 & 0.5 \\
& Donated blood may be sold & - & - \\
& No remuneration (payment) & 1 & 0.5 \\
& Need to donate to friends & 25 & 11.5 \\
& or relatives in the future & & \\
\hline & & &
\end{tabular}

that they need to donate to friends or relatives in the future (Table 4).

Knowledge and attitude levels of the respondents were not found to have statistically significant association with sociodemographic parameters study; but, only sex of the respondents had shown statistically significant association with the practice of blood donation among Wolaita Sodo University Teaching and Referral Hospital health care workers that males were more likely to donate blood than females [AOR (95\% CI): 2.59(1.22-5.49)].

\section{Discussion}

In this institution based cross-sectional study on KAP and associated factors towards blood donation of WSUTRH health care workers, a total of 218 study subjects were involved. Among the respondents, 102 (46.8\%) were in the age group of 26-30 years. The mean and the median age of the respondents were 28.8 and 28 years respectively with a standard deviation of 5.22. This socio-demographic fact of the study result shown that the population was built with younger workers in contrary to some developed countries. This was a very great opportunity to expand blood donation services. It was relatively comparable with the result of the study conducted in Kenya in which most of the blood donors in Nairobi found to be in age between 18 and 28 years [21]. This is an opportunity for blood donation in our study area as opposed to the studies conducted in Australia, Canada and America aging being among the major challenges of blood donation $[1,22,23]$.

As of the finding of this study, the level of knowledge on blood groups and how often an individual can donate blood was good in comparison to the result of the study conducted in Addis Ababa health facilities with this regard [8]. In our study, most of the health care workers had knowledge that a person can be infected by receiving a blood transfusion. On the contrary, in a study conducted in the democratic republic of Congo on assessment of KAP regarding blood donation, 61\% did not know the practice of donating blood and the knowledge of blood donation and it was significantly associated with educational level of the respondents and their religion [24] which was not in our study case. Besides this, our study result was much higher than the report of 2015 WHO regional office for Africa average prevalence of adequate knowledge towards blood donation and the study conducted in Samara, Ethiopia [25, 26]. Unlike the study conducted in Addis Ababa, in this cross-sectional study, there was no significant statistical association of the level of knowledge with the sex of the respondent and other variables (Ambaye Dejen: Knowledge, attitude, practice and factors associated towards blood donation among health care workers in Tikur Anbessa specialized hospital, Addis Ababa, Ethiopia, unpublished).

On the assessment of attitude level, 58.5\% of the respondents were found to be with a good attitude towards blood donation. This result was lower than the result of the studies conducted in Addis Ababa (Ambaye Dejen: Knowledge, attitude, practice and factors associated towards blood donation among health care workers in Tikur Anbessa specialized hospital, Addis Ababa, Ethiopia, unpublished) [8]. Even though 99.1\% responded that blood donation is good, only $57.8 \%$ reported that voluntary donor is the best source of blood donation as of our study finding. This was much below the WHO recommendation of $100 \%$ unpaid voluntary blood donation [23] though higher than the result of a study conducted in Nigeria [4]. Unexpectedly, nearly one third $(32.6 \%)$ of the respondents answered the replacement donor as if the best source of blood which ratified the declined attitude of the respondents as they were health care professionals. On its top, the study participants' willingness to donate blood was found to be low as compared to the result of the study conducted at Ambo town in which $100 \%$ of the respondents were willing to donate blood in the future and $70 \%$ in the study conducted in Addis Ababa [11] (Daniel Negash: Willingness to voluntarily donate blood among high school students in Addis Ababa: assessment of determinants using the theory of planned behavior, unpublished). 
In this study, only $21.6 \%$ of participants were found to have good practice towards blood donation and age groups less than 30 years and physicians were more frequently donating than others. The practice of blood donation was too much lower when compared to the practices in Austria (66\%), France (52\%), Greece and Cyprus (51\%) [22, 27]. It was nearly similar to the result of the studies conducted in Ambo University, Gondar and Addis Ababa, Ethiopia (Ambaye Dejen: Knowledge, attitude, practice and factors associated towards blood donation among health care workers in Tikur Anbessa specialized hospital, Addis Ababa, Ethiopia, unpublished) $[11,16]$. These discrepancies and similarities might be due to the socioeconomic status and awareness level of the participants as the practice of blood donation was depicted to be higher in developed countries aforementioned.

Religious background of the health care workers did not affect their attitude towards or likelihood of donating blood in our study; rather, sex of the respondents had a statistically significant association with the practice of blood donation where males were more likely to donate blood than females [AOR (95\% CI): 2.59(1.22-5.49)]. This finding was in concordance with the findings of a study conducted in Nigeria [28]. Perhaps, this might be due to the burden of females as a matter of their extensive involvement in routine household activities with low nutritional security in the study area and lower hemoglobin levels due to menses paving a way for the development of anemia precluding blood donation [29]. Added to this, among the respondents never experienced blood donation in their lifetime, $65.5 \%$ didn't practice blood donation because they were not approached to donate. This was relatively congruent to the result of the study conducted in Cameroon in which $60 \%$ had not previously been asked to donate blood [30].

Therefore, pieces of trainings have to be facilitated by the institution for health care workers to update their knowledge and attitude with the increasing demand for blood transfusion with due motivational schemes. On its top, the blood banks should facilitate pieces of trainings and make the services more accessible to health care workers in order to get regular blood donors.

However, the present study has some expected limitations. The limitation of the study could be the cross-sectional design used which might not define the cause-effect relationship of the factors with the KAP of blood donation, the use of only quantitative data without triangulating with qualitative due to resource shortage, and not using a validated questionnaire for data collection.

\section{Conclusions}

According to this institution-based cross-sectional study, even though the overall level of knowledge was satisfactory, nearly half of the respondents' attitude on blood donation was unexpectedly poor. The willingness to donate blood if called upon or reminded to do so and the practice of blood donation were also poor. Female respondents were found to have poor practice towards blood donation than males. Not approaching to donate was the leading reason for non-donors. Hence, health care workers are demanded to update their knowledge and build psychological benefits of blood donation in order to save lives. On its top, blood banks have to make their services more accessible to health care workers in order to get regular blood donors. Further studies should be conducted on the KAP of blood donation from the general public angle so that the service be scaled up as per the increasing demand.

\section{Additional file}

Additional file 1: Questionnaire. The self-administered questionnaire used for assessment of knowledge, attitude and practice and associated factors of blood donation among health care workers in Ethiopia. (PDF 305 kb)

\begin{abstract}
Abbreviations
AIDS: Acquired immune deficiency syndrome; CDC: Centers for disease control; CMV: Cytomegalovirus; HCV: Hepatitis C virus; HIV: Human immunedeficiency virus; KAP: Knowledge, Attitude, and practice; NBTS: National blood transfusion services; PEPFAR: President's emergency plan for AIDS Relief; RTA: Road traffic accidents; SNNPR: Southern nations, nationalities people region; WHO: World Health Organization; WSUTRH: Wolaita Sodo University Teaching and Referral Hospital
\end{abstract}

\section{Acknowledgments \\ The authors are grateful to the Wolaita Sodo University for giving an opportunity for the research and providing conducive environment in general and the WSUTRH and its health care workers in particular for their unreserved cooperation in making this study be a fruitful work.}

\section{Funding}

Not applicable.

Availability of data and materials

All relevant data are included in the manuscript and Additional file 1.

\section{Authors' contributions}

DM: has made substantial contributions to conception and design, acquisition of data, analysis, and interpretation of data. FY: has made substantial contributions to conception and design, acquisition of data, analysis, and interpretation of data. MLB: Has made substantial contributions to conception and design, acquisition of data, analysis, and interpretation of data. All the authors have been involved in drafting the manuscript and revising it critically for important intellectual content, and; have given final approval of the version to be published.

\section{Ethics approval and consent to participate}

Ethical clearance was taken from Wolaita Sodo University College of Health Sciences and Medicine Ethical Review Committee established as per National Ethics Review committee Guideline (Federal Democratic Republic of Ethiopia Ministry of Science and Technology: National Research Ethics Review Guideline, unpublished) and verbal consent was obtained from all study subjects with ethical review committee approval due to the fact that the data collected were not invasive with minimal health impact; hence, ascertained that the participation was voluntarily. The study participants' code numbers were used rather than personal identifiers. Finally, all questionnaires were kept for an intended purpose only. 


\section{Consent for publication}

Not applicable.

\section{Competing interests}

The authors declare that they have no competing interests.

\section{Publisher's Note}

Springer Nature remains neutral with regard to jurisdictional claims in published maps and institutional affiliations.

\section{Author details}

${ }^{1}$ College of Health Sciences and Medicine, Wolaita Sodo University, Wolaita Sodo, Ethiopia. ${ }^{2}$ ALERT Hospital, Addis Ababa, Ethiopia.

Received: 24 August 2018 Accepted: 18 April 2019 Published online: 15 May 2019

\section{References}

1. Allerson J. Assessment of Selected University Students' knowledge of blood donation and the relationship with intent to donate blood. In: Theses, dissertations, and other capstone projects; 2012. Paper 56.

2. Nwabueze S, Nnebue C, Azuike E, Ezenyeaku C, Aniagboso C, Ezemonye O, et al. Perception of blood donation among medical and pharmaceutical science students of Nnamdi Azikiwe University. Awka. Open J Prev Med. 2014:4:515-22

3. WHO. Blood transfusion safety. In: The clinical use of blood handbook; 2001.

4. Salauden AG, Odeh E. Knowledge and behavior towards voluntary blood donation among students of a tertiary institution in Nigeria. Niger J Clin Pract. 2011;14:303-7.

5. WHO. Towards $100 \%$ voluntary blood donation: A global framework for action. 2010. http://www.who.int/bloodsafety/publications/9789241599696/en/. Accessed on 4 Feb 2019.

6. WHO. Safe blood needed to save mothers, Blood donor day 2014. http:// www.who.int/mediacentre/news/releases/2014/world-blood-donor-day/en/. Accessed on 4 Feb 2019.

7. WHO. Campaign essential for world blood donor day 2015. http://www.who. int/campaigns/world-blood-donor-day/2015/en/. Accessed on 4 Feb 2019.

8. Bantayehu D. Knowledge, attitude and practice of voluntary blood donation and associated factors among health care providers in Addis Ababa health facilities, Ethiopia. Occup Med Health Aff. 2015;3:209.

9. United States PEPFAR. Report on Blood safety and HIV/AIDS (2006). http:// www.pepfar.gov/reports/progress/76858.htm. Accessed on 4 Feb 2019.

10. Nigatu A, Demissie DB. Knowledge, attitude and practice on voluntary blood donation and associated factors among Ambo University regular students, ambo town, Ethiopia. J Community Med Health Educ. 2014;4:315.

11. BSSP. Ethiopian National Blood Bank Service. https://www.jembi.org/bsspimplementaitons/bssp-ethiopia-national-blood-bank-service/. Accessed on 5 Feb 2019.

12. Mulatu K, Hailu T, Yegezu A, Tena B. Assessment of knowledge, attitude and practice on blood donation in Aman sub-city residents, southwest, Ethiopia, 2015. Health Sci J. 2017:11:485

13. Ethiopia: Blood donation, its use and means to do. https://allafrica.com/ stories/201509110975.html. Accessed on 28 Jan 2019.

14. National blood bank establishment council of ministers regulation no. 330/2014. Federal Negarit Gazeta of the Federal Democratic Republic of Ethiopia. 2015. https://chilot.me/wp-content/uploads/2017/04/regulationno-330-2014-national-blood-bank-service-establishment.pdf. Accessed on 28 Jan 2019.

15. WHO. Blood donor counseling implementation guidelines. 2014. https:// apps.who.int/iris/handle/10665/163001. Accessed on 4 Feb 2019.

16. Arage G, Ibrahim S, Adimasu E. Blood donation practice and its associated factors among health professionals of University of Gondar Hospital, Northwest Ethiopia: a cross-sectional study. BMC Res Notes. 2017;10:294.

17. Tadesse T, Berhane T, Huluf Abraha T, Gidey B, Hagos E, Grum T, Gerensea $H$. Blood donation practice and associated factors among health professionals in Tigray regional state public hospitals, northern Ethiopia. BMC Res Notes. 2018;11:677.

18. Tedla SB, Sudhakara Reddy B. The kingdom of Wolaita (Ethiopia): military organization and war, to 1894. Galore Int J Appl Sci Humanit. 2018;2:9-17.
19. Central Statistics agency. Summary and Statistical Report of the 2007 Population and Census. 2008. https://www.ethiopianreview.com/pdf/001/ Cen2007_firstdraft(1).pdf. Accessed on 4 Feb 2019.

20. Karobi D. Knowledge attitude and practices of blood donors toward blood donation. J Postgrad Med Educ Res. 2014;48:123-7.

21. Njambi Njuguna. Factors influencing blood donation at selected sites in Nairobi, Kenya. 2012. http://ir.jkuat.ac.ke/handle/123456789/1468. Accessed on 23 Aug 2018.

22. Morris, A. Blood donor motivation: a phenomenological study of young male donors. 2011. http://ro.ecu.edu.au/theses_hons/19. Accessed on 23 Aug 2018.

23. Drackley A, Hons B.A. How generous are we? Forecasting and demographic correlates of blood donation. https://macsphere.mcmaster.ca/bitstream/ 11375/9460/1/fulltext.pdf. Accessed on 23 Aug 2018.

24. Kbinda JM, Serge M, Sylvain R, Dramaix M-w. Assessment of knowledge, attitude and practice of the general population of Bukavu in the Democratic Republic of Congo blood donation and blood transfusion. Health. 2014;6:2525-34.

25. WHO: Regional Office for Africa; Blood safety in Ethiopia. 2015. www.afro. who.int/../ethiopia. Accessed on 20 Aug 2018.

26. Tadesse W, Ayalew Y, Yisma E, Liben ML, Wudu M. Knowledge, attitude and practice and associated factors towards voluntary blood donation among regular health science students of Samara University, Ethiopia. Health Sci J. 2018;12:542.

27. Special Eurobarometer Survey: Blood donation and blood transfusions. 2009. https://www.gesis.org/?id=2659\&tx_eurobaromater_pi1\%5Bvol\%5D= 2659\&tx_eurobaromater_pi1\%5Bpos1\%5D=525. Accessed on 5 Feb 2019.

28. Nwogoh B, Aigberadion U, Nwannadi Al. Knowledge, attitude, and practice of voluntary blood donation among healthcare workers at the University of Benin teaching hospital, Benin City, Nigeria. J Blood Transfus. 2013. https:// doi.org/10.1155/2013/797830 Accessed on 5 Feb 2019

29. Central Statistical Agency (CSA) [Ethiopia] and ICF. Ethiopia Demographic and Health Survey. Addis Ababa, and Rockville: CSA and ICF; 2016.

30. Sigurd Christoffer Rolseth, Pal SverreStange. Attitudes to blood donation in Ngaoundere, Cameroon. 2012. (Unpublished). https://www.duo.uio.no/ handle/10852/35686. Accessed on 5 Feb 2019.

\section{Ready to submit your research? Choose BMC and benefit from:}

- fast, convenient online submission

- thorough peer review by experienced researchers in your field

- rapid publication on acceptance

- support for research data, including large and complex data types

- gold Open Access which fosters wider collaboration and increased citations

- maximum visibility for your research: over $100 \mathrm{M}$ website views per year

At $\mathrm{BMC}$, research is always in progress.

Learn more biomedcentral.com/submissions 